\title{
A NEW SUBFAMILY IN THE JASSIDAE.
}

\author{
By CARL F. BAKER, POLYTEChNiC INSTitute, AUbURN, AlA.
}

In the National Museum Collection there are several specimens of what is probably the most remarkable Jassoid insect yet discovered in North America. They are from California and were collected by Mr. Koebele. The peculiarities of form and structure are matched by several other Jassoids, its general appearance being that of an Acocephalid, yet the position of the ocelli combined with its other characters, render it unique. For while in general structure it is a Jassid (sens. strict.), yet in the position of the ocelli it is a Bythoscopid, as these organs are well down on the face. But the vertex is thin and foliaceous, somewhat expanded before the eyes, concave above and curved upward, and nearly half again longer than the pronotum, thus removing it far from all Bythoscopid genera. In the passage forward and downward of the Jassid ocellus, this insect might have sprung from the original Bythoscopid root, but its development has certainly been along entirely separate and distinct lines. A more plausible theory is that there was no movement of ocelli except toward each other, the edge of the vertex just above the ocelli becoming extended far forward over them in the form of a thin plate. This is borne out by the fact that the ocelli are still on a line between the upper edges of eyes. This insect is the sole representative of a group which is further removed from the Bythoscopinae, than the Ulopinae and Paropinae are from the Jassinae, or the Ledrinae from the Tettigoninae. I name this new genus and subfamily in honor of the discoverer.

Koebeliinae, n. subfam. Ocelli far below anterior edge of head and distant from the eyes, though on a line between upper edges of eyes, Vertex thin, foliaceous, concave, bent upward, slightly expanded before eyes, and longer than pronotum.

Koebelia, n. gen. Head broader than pronotum, vertex half again as long. Ocelli as near to median line as to eyes. Elytra as long as abdomen (exclusive of $q$ genitalia), subcoriaceous, without an appendix. Veins weak; four apical and two anteapical cells, basal transverse vein entering radial cell; claval veins two. Type:-

Koebelia californica n.sp. + . Length to tip of ovipositor, $7 \mathrm{~mm}$. Light ferruginous, variously clouded with paler. Face above dark, with a transverse angulate lighter line which medially sends three branches to tip of vertex. Vertex with a median lighter area, which is broader anteriorly; extreme anterior edge of vertex dark with fine light interruptions. Pronotum with a median longitudinal light line. Elytra opaque whitish, with three irregular, darker, transverse bands, the first indistinct, the second at middle of elytra, and the third between second and apex. All the veins and margins of elytra with sparse black points.

Vertex broadly subtriangular anteriorly, length three-fourths of breadth between eyes. Front long, narrow, gradually narrowed to clypeus, frontal sutures extending only to 
ocelli. Clypeus small, long oval, the pointed end considerably exceeding genae, the latter being extremely narrow below the lorae. Below the eyes the sides of the genae are strongly obtusely angulate, the margin from this anguiation to the lorae nearly horizontal. Pronotum short, width two and a half times length, anterior and posterior margins subparallel except at sides. Scutel rather small, shorter than pronotum. Ovipositor longer than rest of venter, exceeding the elytra by nearly a millimeter. Last ventral segment about as long as preceding, hind margin truncate.

8. Length $5 \mathrm{~mm}$. Colors very much darker, nearly all below with anterior femora, black; the only light portions of the face being the lines above, and a large area on either side below.

Collected during August in Placer Co., California, by Mr. A. Koebele.

\section{INSECTS COLLECTED AT JACKMAN, MAINE.}

BY F. L. HARVEY AND O. W. KNIGHT, ORONO, ME.

In August, I $\$ 95$, we spent a week in the vicinity of Jackman on the Canadian Pacific R. R. near where it crosses the Maine boundary, and the following insects were taken. We selected what seemed to be a very promising place for sugaring and laid a route nearly a mile long including all kinds of ground. We went over it twice each evening for three nights. The only remarkable thing noticed was the dearth of nightflying insects taken. The fields were alive with locusts and crickets. We were quite surprised to find the chinch bug in dry pastures on the high hills in Moose River township. The locality is fully 300 feet above the drainage of Moose River at Jackman. Moose River, after traversing several lakes, enters the North end of Moosehead Lake. The altitude at which the chinch bugs were found is remarkable, also the locality is nearly roo miles farther north than Fryeburg, Me., where this insect infests one area covering many square miles.

\section{Orthoptera.}

Gryllus luctuosus Serville. Very common under rocks and piles of stones in the fields and pastures. It was by far the commonest insect to be found in the vicinity of Jackman.

Nemobius fasciatus De Geer. Associated with the preceding species but not nearly so common.

Ceuthophilus maculatus Harris. Not very common. A few were found under logs and stone piles.

Scudderia curvicauda De Geer. Common in bushes and shrubbery.

Xiphidium fasciatum De Geer. Very common in fields and meadows.

Pezotettix glacialis Scudder. Rare. Five specimens were taken in open woods and bogs along a deserted wood road. These were found at an unusually low altitude for this species.

Melanoplus femoratus Burmeister. Common in fields and meadows.

Melanoplus atlanis Riley. Common in fields etc. 

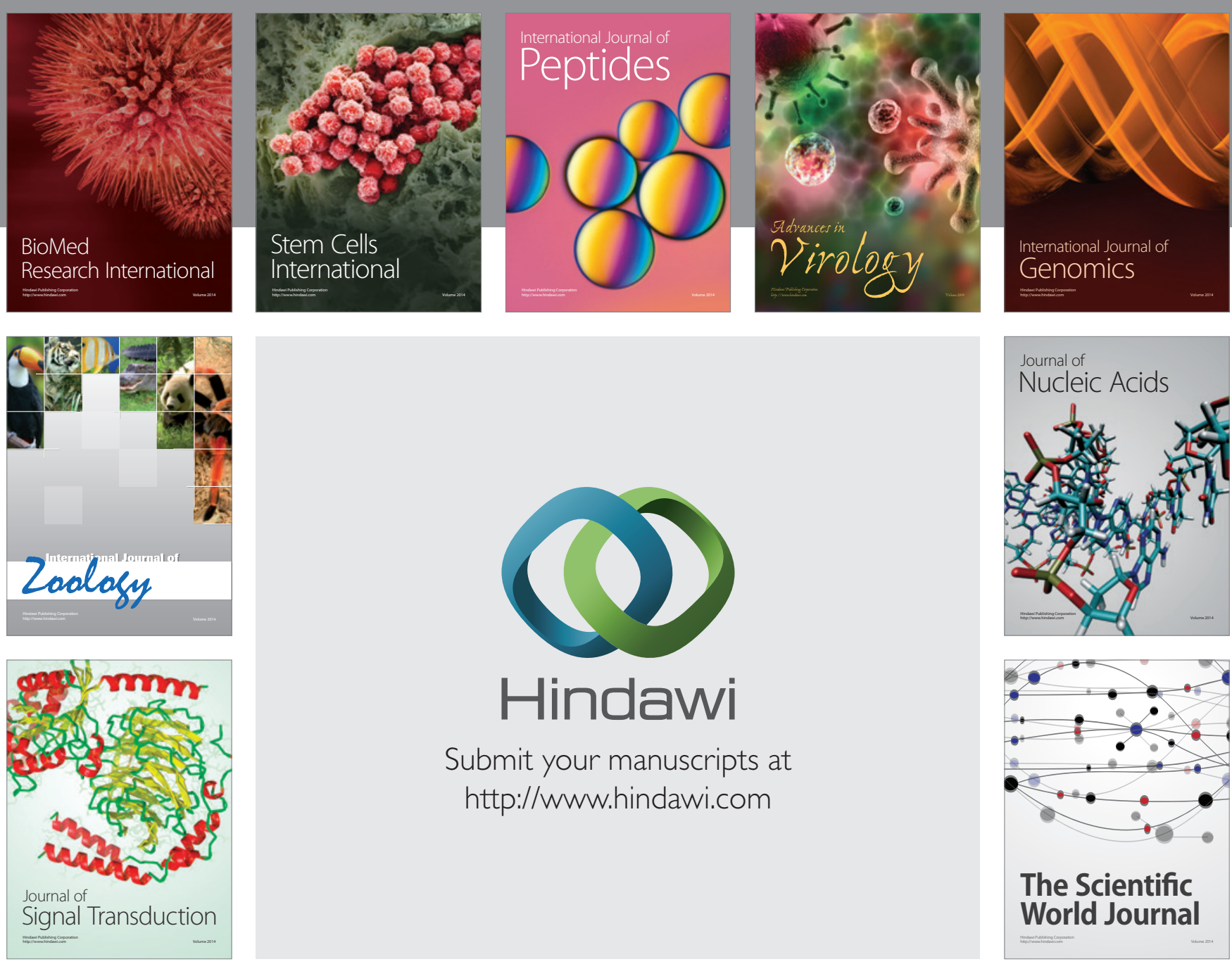

Submit your manuscripts at

http://www.hindawi.com
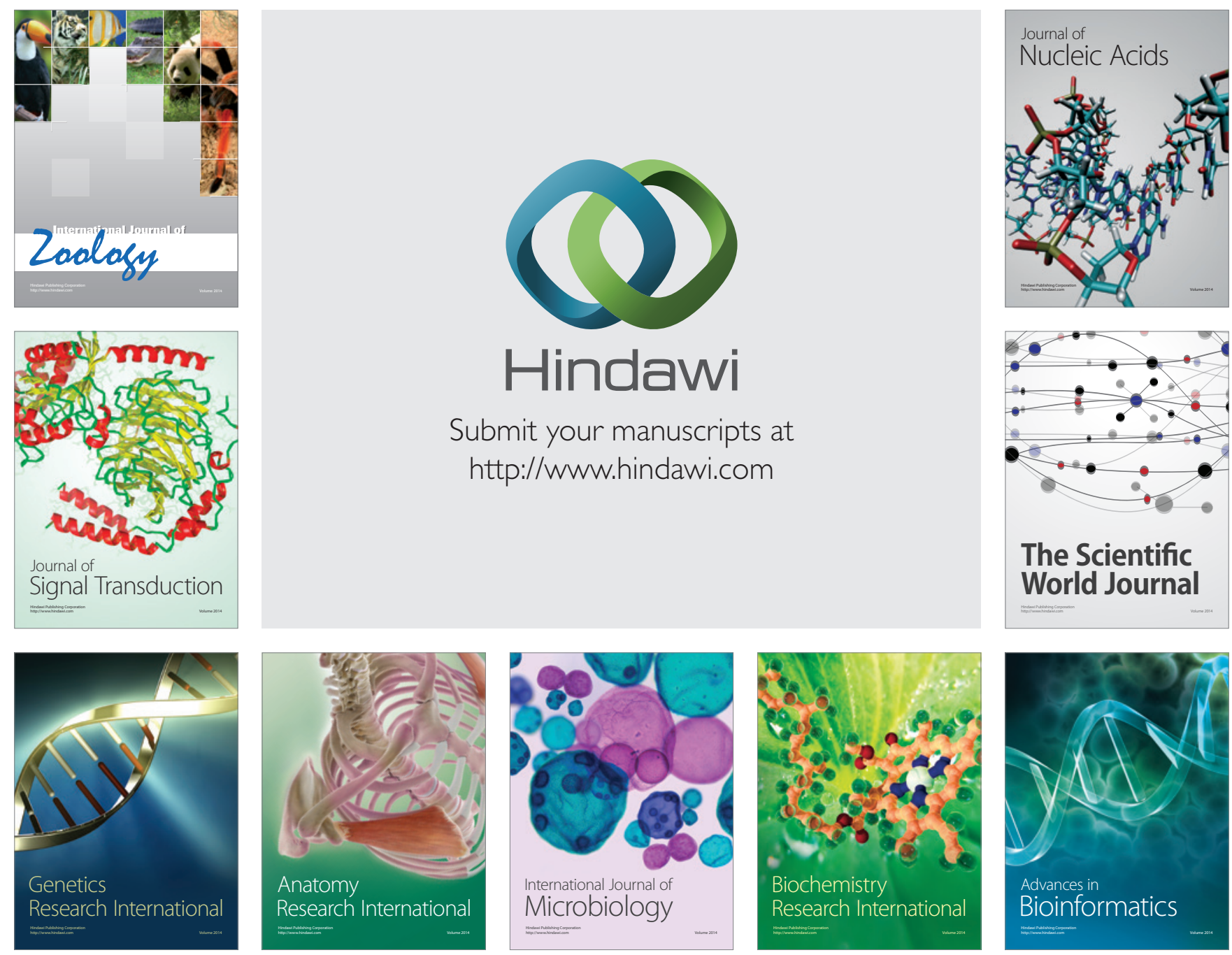

The Scientific World Journal
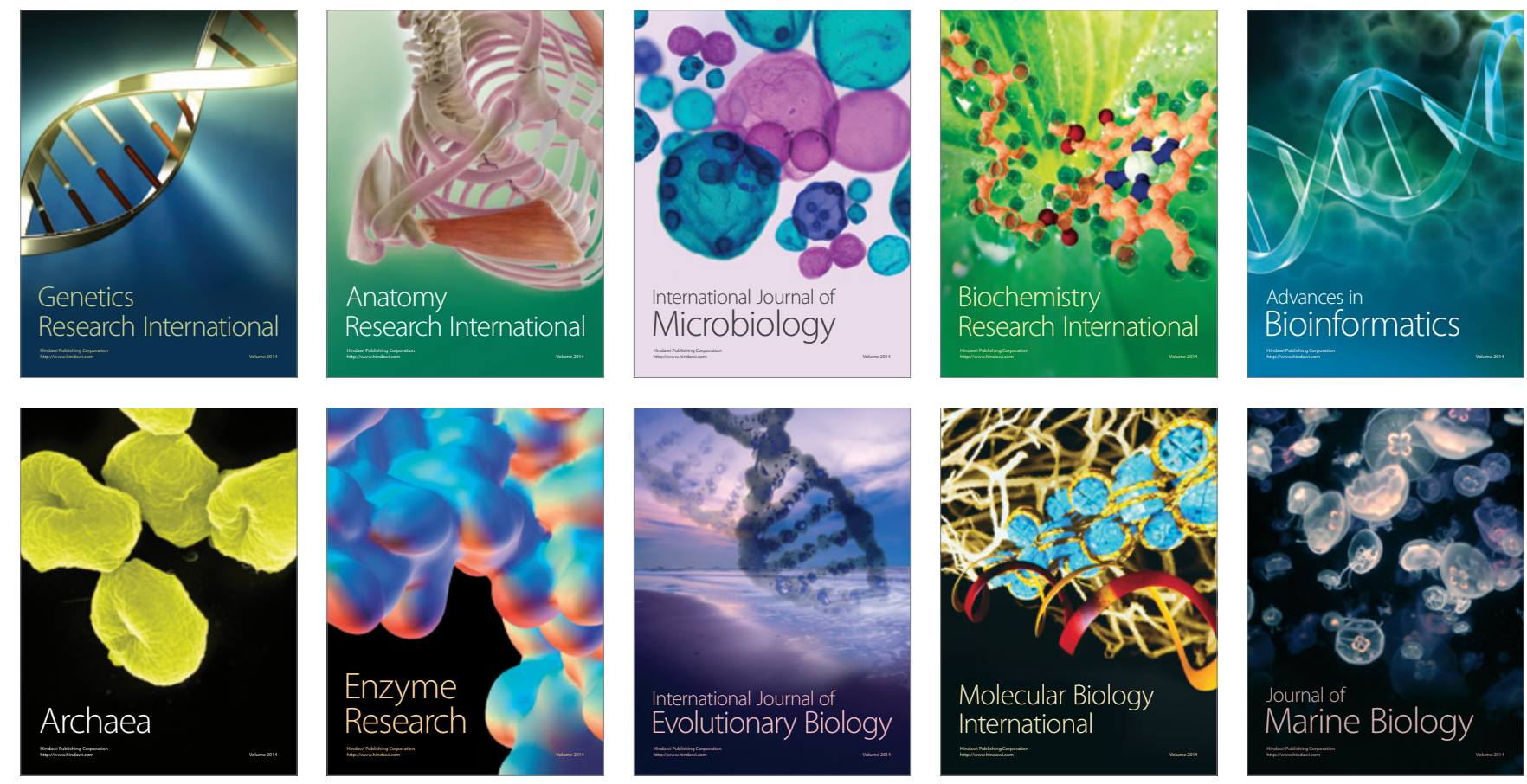